International Journal of Scholarly Papers for Media and Communications

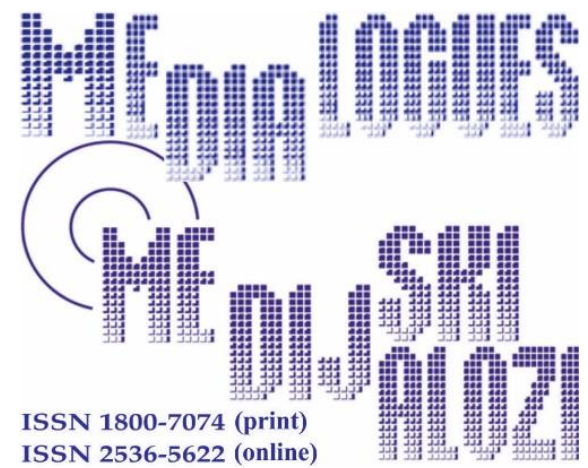

Bachovska, J., Rajcinovska Pandeva, I. (2012), „Future of Journalism Education Challenges and Prospects",Media Dialogues / Medijski dijalozi,

Vol. 14, No. 3, pp. 71-83.

\title{
Future of Journalism Education - Challenges and Prospects
}

\author{
Assistant professor JASNA BACHOVSKA, \\ Faculty of Law "Iustinianus Primus", \\ Skopje, Macedonia Teaching assistant
}

\section{IRENA RAJCINOVSKA PANDEVA, MSC}

Faculty of Law "Iustinianus Primus",

Skopje, Macedonia

\begin{tabular}{|c|c|}
\hline $\boldsymbol{A} \boldsymbol{R} \boldsymbol{T} \boldsymbol{I} \boldsymbol{C L} \boldsymbol{E}$ & Received: January 02, 2021 / Revised from: February 02, 2021 \\
$\boldsymbol{I} \boldsymbol{N} \boldsymbol{F} \boldsymbol{O}$ & Accepted: March 04, 2021 / Available online: July 15, 2021 \\
\hline $\boldsymbol{D O I}$ & doi.org/10.14254/1800-7074/14-3/5 \\
\hline
\end{tabular}

\begin{abstract}
Our world is changing rapidly and we are all witnesses to that change. Also we are aware of the fact, what was it like to live here 20 years ago and now. That is
\end{abstract}


caused by the large development which occurred in the field of technology in short period and the appearance of the world wide web or more likely said the internet. There were times where in order the informa- tion to be transferred from one place to other, months or in some cases years were needed. But nowadays the news are transferred expressly and their effect is broader. In this so called modern world we are not only the traditio- nal consumers, but also known as the interactive users and creators, broad-casters and publishers of information. We may ask why do we need journa- lists as professionals? The role of the journalists may be changing, the sources may be diversified, the core of traditional media may be shifting to other forms and contents but journalism is still a precious sphere where news are systematically gathered, analyzed and disseminated. In order to reach this level we must have proper journalism education. According to Newton hypothesis is that four transformational trends 1. Journalism and communication schools better connecting to the intellectual life of the entire university 2. Journalism and communica-tion schools as content and technology innovators. 3. Journalism and communication schools as the master teachers of open, collaborative approaches. 4. Journa- lism and communication schools as digital news providers who understand the media ecosystems of their communities) are the keys to the success of journalism schools. This will hopefully add impetus to change our rules and tools, standards and practices, laws and statutes, and suite them best to serve our needs. A prerequisite for improvement of the society and healthy citizens is how we educate and how we engage our journalism students and ourselves in a mea-ningful and preferably nonhierarchical dialogue because this is what can de-termine how professional journalism is made. That is where the future jour-nalism education needs to be headed if the main aim is to become more pro-fessional and gain with more confidence and respect.

KEYWORDS: Journalism, communications, education, change.

„In journalism school they taught me the story was the only thing that mattered. Make a story good enough, it will change the world.

Well... A great story can change the world, under the right circumstances. But an equally great story will change absolutely nothing, if conditions aren't right. Why... Because the stories we love so much are not the only things that matter.

Not just reaching but engaging communities matters.

Portable, personal, participatory technology matters. Business models that support quality journalism matter.

The whole media ecosystem matters ${ }^{1}$ ".

Eric Newton

\footnotetext{
${ }^{1}$ Eric Newton (Vice president for journalism at Knight Foundation) remarks to journalism educators at the pre-conference workshop titles "Journalism Schools as News providers: Challenges and Opportunities", held on the 3rd of August 2010 in Denver, USA
} 


\section{INTRODUCTION}

The world is changing every minute of every day in various manners. There were times when an event happening thousands of kilometers away would reach us after it has already occurred and would hear and see only the aftermath. Nowadays, the news ${ }^{2}$ travels quickly and often with perfect punctuality as if it has been composed previously and intentionally. Sometimes it is a result of news coverage on the very spot (breaking news report), but the fact is that often its source is the citizen that is affected by or has witnessed it in live. There were also times, not so long ago, when we were not aware or alert about an incident or occurrence whose implications would impact our life in some manner. Now, thanks to the media possibilities we are able to state our views or even contribute to its development or its conclusion ${ }^{3}$. And even further, as the news environment changed, we became radically different users inste- ad of being traditional consumers. We are now content creators, users of twoways communication tools, distributors, broadcasters and publishers, information evalua- tors all in all pervasive clients that blend the old and new media, and choose how and what news we get or circulate ${ }^{4}$. New trends in communication and new technologies (as opposed to the times of industrial media) have allowed speedy and voluminous distribution not only of variety of information but also information with mounted value, velocity and vibrancy ${ }^{5}$. 2 The 1947 Hutchins Commission Report, A Free and Responsible Press, defined news as "truthful,
comprehensive, and intelligent account[s] of the day's events in a context which gives them meaning".
Cited from Informing communities: Sustaining Democracy in the Digital Age. Posted by KnightComm
on Apr 07, 2010 in Civic Engagement, Digital Literacy, Local Journalism, Open Government, Public
Service Media, Universal Broadband. Available online at http://www. knightcomm.org/read-the-
report-and-comment/. Further reading The Commission on Freedom of the Press, A Free and Respon-
sible Press - A General Report on Mass Communication: Newspapers, Radio, Motion Pictures, Maga-
zines and Books, 20 (1947).

${ }^{3}$ One highly interesting perspective is being shown by Eric Schmidt, former CEO of Google. Namely, he estimates that humans now create as much information in two days as we did from the appearance of Homo sapiens through 2003. "The Information needs of communities", Steven Waldman and the Working Group on Information Needs of Communities, Federal Communications Commission, July 2011, http://www.fcc.gov/inforneedsreport.

${ }^{4}$ Dealing with User-Generated Content: is it Worth it?, by Paul Hamleton, from The Future of Journalism Papers from a conference organised by the BBC College of Journalism, edited by Charles Miller, CoJo Publications: 1, BBC College of Journalism 2009

5 “...The democratization of media is well under way. This takes two major forms. First, the tools of creation are increasingly in everyone's hands. The personal computer that I'm using to write this essay comes equipped with media creation and editing tools of such depth that I can't begin to learn all their capabilities. My phone boasts video record- ing and playback, still-camera mode, audio recording, text messaging, and GPS location, among other tools that make it a powerful media creation device. Second, we can make what we create widely accessible. With traditional media, we produced something, usually manufactured, and then distributed it-put it in trucks or broadcast it to receivers in a one-to-many mode. Today, we create media and make it accessible: People come and get it. This distinction is absolute crucial, because although there is plainly an element of distribution here, even in the traditional sense, the essential fact in a one-to-one or many-to-many world is availability. This democratization gives people who have been mere consumers the ability to be creators. With few exceptions, we are all becoming the latter as well as the former, though to varying degrees. Even more exciting, media democratization 
The impact of it has affected our living more rapidly, frequently and profoundly that we can even word ${ }^{6}{ }^{6}$. Bearing this growing sense of complexity in this world of ours, one would ask what about journalism, where is the role of journalist and how do we incorporate these trends in the future professional journalist education?

\section{MEDIA DEVELOPING TENDENCIES}

Lately, next to the so called traditional media - radio, television and print, the fourth kind of media and consequently journalism appeared - online media i.e. online journalism. The latter is usually seen as gathering and distributing original news content on the Internet. However, as Bardoel and Deuze note: "research shows that the genre has outgrown the status of 'shovel ware' production: online journalists do not merely repurpose content for the Web, and more of them are generating original content" ${ }^{\text {" }}$. Some forms of live news reporting like Carvin ${ }^{8}$ tweets act as transponders between different media types and do get enormous followers within the public but on the other hand they seem to be contributing largely to skepticism surrounding the

also turns creators into collaborators. We have only begun to explore the meaning, much less the potential, of this reality. Media saturation requires us to become more active as consumers, in part to manage the flood of data pouring over us each day but also to make informed judgments about the significance of what we do see. When we create media that serves a public interest or journalistic role, we need to understand what it means to be journalistic, as well as how we can help make it better and more useful. This adds up to a new kind of media literacy, based on key principles for both consumers and creators. They overlap to some degree, and they require an active, not passive, approach to media". Dan Gillmor, Principles for new media literacy, MEDIA RE:PUBLIC, Papers 2008 Berkman Center for Internet and Society at Harvard University. http://cyber.law.harvard.edu/sites/cyber.law.harvard. edu/files/Principles\% 20for\%20a\%20New\%20Media\%20Literacy_MR.pdf

${ }^{6}$ Today, people "meet their information needs through broadband service and home computers or Webenabled mobile phones. At their desks or just walking their neighbourhoods, they have access to more information than many nations hold in all the books in their national libraries. Today's information consumers can pull together the news they want to follow in a convenient Web page. They can apply online for a job, a loan, or college admission. They can check their children's school lunch options and keep track of homework assignments. Before they go to the doctor, they can arm themselves with information from health Web sites or online support groups. They do not overdraw their bank accounts because they can check balances online and move funds from one account to another. They pay bills efficiently without ever using a postage stamp". Informing communities: Sustaining Democracy in the Digital Age. Posted by KnightComm on Apr 07, 2010 in Civic Engagement, Digital Literacy, Local Journalism, Open Government, Public Service Media, Universal Broadband. Available online at http://www. knight comm.org/read-the-report-and-comment/

${ }^{7}$ Bardoel, Jo and Deuze, Mark, Network Journalism: Converging Competences of Media Professionals and Professionalism. Australian Journalism Review, Vol. 23, No. 2, 2001, pp. 91-103.

${ }^{8}$ Andy Carvin (social media strategist for US public service radio broadcaster NPR) became famous to the general public due to his over 1200 tweets made during the Libya uprising within 48 hours and grabbed the attention of the media specialists due to his mastery of aggregated and verified real time news Twitter. "News organisations have become increasingly fascinated by Carvin's experiments as the value of insight, and the expertise required in aggregating and filtering information on social networks, has become more apparent". See more at http://www.guardian.co.uk/media/2011/ sep/04/andy-carvin-tweets-revolutions 
matter of quality over quantity in news production and the question of value. Orthodox supporters of the latter tend to regard the tweets, the social media and blogs as free news sources of small value where the technology facilitates communication within diverse public without the intermediation of professionals (educated and expert journalists $)^{9}$. On the contrary the traditional media is still regarded as the only (or most) competent source of news because it is dependent upon old-time journalist skills as researching, writing, packaging and presenting articles. Another aspect of the core of this ongoing debate is the idea of "digital first, print last $t^{10 "}$ which seems to be settling in nicely in important media houses in western countries. The $3 \mathrm{R}-$ three revolutions: broadband, wireless connectivity and social networking have produces more digital than print audiences, more online than old-fashioned paper news, so the media ecosystem has changed and will continue to change. As Smith observes, "nearly a quarter of the world's population use the internet. Every year 200 million join the online revolution. She underlines that according to Google, the internet is the fastest growing communications medium in history. When the internet went public in 1983 there were 400 servers. Today there are well over 600 million" $"$.

These tendencies entail secure grounds both for new and old media. The process requires a delicate balance not so much for the sake of the traditional media as much as for the health of the public sphere and informed citizenry. The source of news ${ }^{12}$ is important just as is its diversification. However, in-depth analyses, investigative work and expert insight can not and should not be replaced by tweets, facebook status updates and comments, email notices, cell phone transmissions and citizen journalism ${ }^{13}$ all together. They can prove as sufficient in breaking news but even then one should question the source, the background and its competence. What is also exceedingly crucial is the quality control, the available resources to inquiry the story, the know-how necessary to conduct the research and finally the grit of the

\footnotetext{
${ }^{9}$ For more on the devastating effect of emerging new media on traditional media see in "The Information needs of communities", Steven Waldman and the Working Group on Information Needs of Communities, Federal Communications Commission, July 2011, http://fcc.gov.infoneedsreport.

${ }^{10}$ The saying became popular when John Paton (chief executive of the American newspaper company Journal Register) used it to explain the importance of digital medium in the future, underlining that "print is not dead (yet). It means that digital is the future and must determine both news process and business strategy. Print continues while it still supports itself, if it is less expensive to produce (a byproduct) or uniquely valuable (a luxury)". Further reading at http://jxpaton.wordpress.com/; http:// www. guardian. co.uk/media/2011/jun/26/digital-first-what-means-journalism

${ }^{11}$ From Introducing Multimedia to the Newsroom, by Zoe Smith, from The Future of Journalism Papers from a conference organised by the BBC College of Journalism, edited by Charles Miller, CoJo Publications: 1, BBC College of Journalism 2009

12 And as noted in Knight Commission's Report: "the best journalism serves the interests of truth by reporting as fact only what can be verified through multiple trusted sources". Informing communities: Sustaining Democracy in the Digital Age. Posted by KnightComm on Apr 07, 2010 in Civic Engagement, Digital Litera- cy, Local Journalism, Open Government, Public Service Media, Universal Broadband. Available online at http://www.knightcomm.org/read-the-report-and-comment/

${ }^{13}$ One of the most prominent examples of citizen journalism is CNN iReport (a user-generated section of CNN.com. The stories here come from users.) http://ireport.cnn.com/
} 
educated analyst (journalist) to publicly broadcast or publish his findings. Or, as Newton pinpointed it, the whole media eco system matters ${ }^{14}$.

Further more, direct and unlimited access to information, can not be seen as “complete solution to a community's needs because information can overwhelm. Emerging technologies may help people sift, organize and evaluate information. But even tech-savvy individuals are unlikely to possess the institutional resources they need to meet all their personal information needs and objectives without help. No individual can generate all the analysis, debate, context and interpretation necessary to turn raw information into useful knowledge ${ }^{15}$ ". Therefore, journalism is seen as critical intermediating practice of gathering and disseminating news, which is more than necessary to any society, because "individuals and communities depend on news as a critical element of the information ecology" 16 . The role of the journalists may be changing, the sources may be diversified, the core of traditional media may be shifting to other forms and contents but journa- lism is still a precious sphere where news are systematically gathered, analyzed and disseminated with necessary note of public accountability and persistence to their responsible task of intermediaries ${ }^{17}$. That is why journalists as skilled practitioners are needed. "They ask tough questions. They chase obscure leads and confidential sources. They translate technical matters into clear prose. Where professionals are on the job, the public watchdog is well fed. Part-time, episodic or uncoordinated public vigilance is not the same"18.

\footnotetext{
${ }^{14}$ Eric Newton (Vice president for journalism at Knight Foundation) remarks to journalism educators at the pre-conference workshop titles "Journalism Schools as News providers: Challenges and Opportunities", held on the 3rd of August 2010 in Denver, USA.

${ }^{15}$ Informing communities: Sustaining Democracy in the Digital Age. Posted by KnightComm on Apr 07, 2010 in Civic Engagement, Digital Literacy, Local Journalism, Open Government, Public Service Media, Universal Broadband. Available online at http://www.knightcomm.org/read-the-report-andcomment/

16 "News can be life-enhancing. It can be decisive to individuals in their personal affairs. Local, national and international events can point the way to important challenges and opportunities. News can affect decisions that are both mundane and essential to personal well-being: where the Board of Education will locate a new school, whether plans are advancing for light rail through city neighbourhoods, early reports of a possible flu outbreak at a local community college. The news also helps people to connect their private and public concerns. It helps them identify and take advantage of opportunities to put issues of personal importance on the public agenda. To serve their individual purposes, people need continual access to news that is credible, verified and up-to-date. News is also essential for the community as a whole. Community coordination cannot exist without shared news. The dissemination of information, debate and analysis is central to problem solving. The Hutchins Commission emphasized the importance of media's role in projecting a "representative picture of the constituent groups in the society." The news connects sub-communities by letting one neighbourhood know what another neighbourhood is doing and how the affairs of some affect the fortunes of all". Ibid., part I

${ }^{17}$ Ibid., part I

18 Ibid.
} 


\section{JOURNALISM EDUCATION}

The first program for journalism education is said to be established in the USA in 1860 ties. The first journalism school dates from $1908^{19}$. Since that time, journalism studies have become a standard in most major universities. The importance of journalism education relates to the inevitability of professionalization of journalism since more and more journalists enter their profession via journalism schools. This tendency has labeled the 20th century and it is believed to be alive today too. To a greater or lesser degree, journalism schools ${ }^{20}$ all over the globe are conventionally established upon the traditional approaches to journalism education thus incorporating general journalism knowledge and journalism skill training.

According to UNESCO, journalism education should teach students how to identify news and recognize the story in a complex field of fact and opinion, how to conduct journalistic research, and how to write for, illustrate, edit and produce material for various media formats (newspapers and magazines, radio and television, and online and multimedia operations) and for their particular audiences ${ }^{21}$. Further more, according to UNESCO, journalism education should provide prospect students the necessary knowledge and training that reflect essences of journalism ethics and best practices, as well as bestow them with fundamental understanding on the role of journalism in society, and instruct them on how to cover political and social issues of particular importance to their own society by offering courses (some with interdisciplinary character) that can be developed in collaboration with other university programs and departments ${ }^{22}$. In addition, journalism study programs should offer specialized knowledge in various fields of interest, assure the linguistic ability of future journalists necessary for work in their respective country as well as abroad by offering language training (mother tongue and foreign) and teach prospective students on how to adopt technological developments and tools and how to stay in tune with all other changes in news media sector ${ }^{23}$. The later is becoming important in parti-

\footnotetext{
${ }^{19}$ Both, the Missouri School of Journalism (University of Missouri, USA) and the Ecole Supierieure de Journalisme (Paris, France) claim to be the first journalism school. Missouri School of Journalism was founded by Walter Williams and claims to have opened and discussed the question of establishing the school in 1895. Ecole Superieure de Journalisme was established in 1899 or 1910 and claims to have discussed the opening of the school in 1896. Further reading at http://journalism.missouri. edu/about/ history.html and http://www.esj-paris.com

${ }^{20}$ The term school is generally accepted term to name institution or part of an institution (such as: faculty, department, college, division).

${ }^{21}$ Model Curricula for Journalism by UNESCO is a general model that can be tailored to the specific needs of each country. It was prepared by four UNESCO experts and it takes into account the social, economic, political and cultural development of developing countries and emerging democracies, highlighting the link between democracy and journalism and arguing for a more interdisciplinary approach within journalism training institutions. See more at Model Curricula on Journalism education, UNESCO series on journalism education, UNESCO 2007, p. 6.

${ }^{22}$ Ibid.

${ }^{23}$ Ibid.
} 
cular due to the fact that our society now lives, not just with technology but in technology, as Patrao and Figueiredo bluntly put it $^{24}$.

Journalism schools carry heavy responsibility to educate and train future journalists. However, often the schools are perceived to be behind the times and not able to keep up with the latest developments. In some journalism schools, data journa$\operatorname{lism}^{25}$, online journalism ${ }^{26}$, link journalism, collaborative journalism and civic journa lism are still unknown concepts, while in others much of the upper level studies seriously engage with them.

Teaching both new and timeless skills in journalism can be rather challenging. Hence, the new digital reporting skills and use of new technologies as tools in journalism are usually being taught alongside the traditional skills and tools, even thought they may prove as vital for student's interests and more advantageous when seeking employment $^{27}$. Another problem arises from the fact that many schools integrate journalism and (mass media) communication studies jointly. This creates additional confusion in producing journalist profiles which can be easily established by analyzing the job market success and best noted by evaluating the curricula of such schools. Journalism school that tends to provide journalist workers needs tailor made graduate program i.e. programs that are adequate to real time trade requirements. This is why bridging business, education, and training is a conditio sine qua non in journalism education.

\section{EMERGING TRENDS IN JOURNALISM EDUCATION - NEWTON PERSPECTIVE}

By incorporation of long years of experience and in-depth investigation of journalism study programs, Newton underlines four emerging trends in journalism education. The starting assumption of Newton is the idea to teach quality journalism

\footnotetext{
${ }^{24}$ See more in Educating the new generation journalist: From Moodle to facebook, Patrao Carla and Figueiredo Dias Antonio, Center for Informatics and Systems (CISUC) - University of Coimbra, Portugal.

${ }^{25}$ Guardian claims that contrary to the general believe data journalism is not new. Namely, the prove is the very first Guardian - or Manchester Guardian as it then was - issue of May 1821 which contained a table of data a list of schools in Manchester and Salford, with how many pupils attended each one and average annual spending. Further reading at http://www. guardi- an.co.uk/news/datablog/2011/ sep/26/data-journalism-guardian

${ }^{26} \mathrm{~J}$. Bardoel and M. Deuze name online journalism also as digital. "The Internet is changing the profession of journalism in at least three ways: it has the potential to make the journalist as an intermediary force in democracy superfluous; it offers the media professional a vast array of resources and sheer endless technological possibilities to work with; and it creates its own type of journalism on the Net: so-called digital or rather: online journalism". Further reading Bardoel, Jo and Deuze, Mark, Network Journalism: Converging Competences of Media Professionals and Professionalism. Australian Journalism Review 23 (2), 2001, pp. 91-103.

${ }^{27}$ Reinvigorating Journalism Education, A Review of News 21, 2005-2011, June 1, 2011, JM Advisory group, p. 19.
} 
and the idea of fair, accurate and contextual search for truth as its core. His analysis is based on the four basic components of traditional journalism -the journalist, the story, the medium and the audience. He recognizes the fact that they are changing fast and he identifies four developing/transformational trends in journalism education which he also names as meta-trends:

Trend no. I - Journalism and communication schools better connecting to the intellectual life of the entire university (Connecting with the whole University).

This trend, according to Newton is based on idea that during the course of education of future journalists it is necessary to include different parts if the university in order to achieve more comprehensive and detailed teaching. "When you teach students to produce professional quality work while in school, when you teach entrepreneurial journalism, when you teach the specialties of health, business, environmental or other advanced forms of journalism, when you teach it to computer programmers or citizen journalists, you are expanding the definition of who a journalist is and what a journalist can do. This is too big a job for journalism schools to do by themselves" 28 . Hence, he underlines that the need to connect the journalism/ communication school to the intellectual life of the university.

Trend no. II - Journalism and communication schools as content and technology innovators. (Innovating content and technology)

This trend, according to Newton rests on the notion that the technology is advancing more rapidly than anyone can predict. As he notes, it is quite difficult to identify what the future of news will be like, so journalism schools and teachers need to adopt and experiment on leading trends in the trade/profession starting from data visualization, web scraping to computation journalism and even developing new software $^{29}$.

Trend no. III - Journalism and communication schools as the master teachers of open, collaborative approaches. (Teaching open, collaborative models)

This trend, as indicated by Newton is being developed by the necessity of different individuals, organizations and even campuses to work jointly either on a story, project or during teaching classes (exchanging methods, tools and e-learning).

Trend no. IV - Journalism and communication schools as digital news providers who understand the media ecosystems of their communities. (Providing digital news in new engaging ways)

This trend, according to Newton emerged as a result of the trend-setting universities that were prepared to go further in the process of education and realized the necessity to produce real news at the school instead of the option of just teach the

\footnotetext{
${ }^{28}$ Journalism education's four transformational trends, Eric Newton, http://www.knight- foundation. org/blogs/knightblog/2010/8/4/aejmc

${ }^{29}$ Ibid.
} 
students how to do news. Additionally, he annotates the need to engage with the people that were once called audience and to increase the stories' impact by trying to figure our why some stories change the world and others don't. Newton believes that these matters place then in the role not only of news providers but of those who hope to understand the media ecosystem of their communities ${ }^{30}$.

Newton hypothesis is that these four transformational trends are to be considered as keys to the success of journalism schools in from this day forward. He annotates the fact that their content and form can differ and even be altered according to various experiences. Yet, his principal dilemma is whether these trends are to be treated as very best practices of some or just wishful thinking. The only way forward, according to him is to embrace the changes and challenges and discuss the matter. This according to him will hopefully add additional impetus to change our rules and tools, standards and practices, laws and statutes, and suite them best to our needs. His advice is to change it all until the day comes when they are no longer emerging trends but new traditions.

\section{CONCLUSION}

Journalism schools are vital cultural institutions that can influence governmental policies toward open information, accountability and free speech- all of which are critical to the health of a democracy ${ }^{31}$. This is due to the fact that "informa- tion is just as important to the health of the community as safe streets, good health, and clean air" ${ }^{\prime 32}$.

Journalism needs to be credited for fostering and easing the ability of society to maintain free and democratic nature. Or as UNESCO stipulates: we know that journalism, and the educational programs that enable individuals to practice and upgrade their journalistic skills, are essential tools for the underpinning of key democratic principles that are fundamental to the development of every country ${ }^{33}$.

Hemida reminds us that journalists in modern Western societies see themselves as central to the proper functioning of democracy and that news practitioners see it as their responsibility to ensure that citizens have the credible information neces-

\footnotetext{
${ }^{30}$ Ibid.

${ }^{31}$ University Journalism Education: A Global Challenge, A Report to the Center for International Media Assistance, August 1, 2007. http://www.ned.org/cima/CIMA-University_Journalism EducationReport.pdf

${ }^{32}$ Charles M. Firestone, director of the Aspen Institute Communications and Society Program at Informing communities: Sustaining Democracy in the Digital Age. Posted by KnightComm on Apr 07, 2010 in Civic Engagement, Digital Literacy, Local Journalism, Open Government, Public Service Media, Universal Broad-band. Available online at http://www.knightcomm.org/read-the-report-andcomment/

${ }^{33}$ Model Curricula on Journalism education, UNESCO series on journalism education, UNESCO 2007, introduction, p. 6.
} 
sary to govern themselves wisely ${ }^{34}$. He also annotates that both Lippmann and Dewey shared a common belief in the crucial role of the press in a vibrant democracy and while Lippmann envisioned the role of the press as a bridge between the uninformed masses and powerful insiders who help formulate the policies of elected decision makers thus observing the journalists as leaders of the citizenry, Dewey viewed journalists as the teachers of the public ${ }^{35}$. Now, whether we agree with the latter or the former, the fact of the matter is that Lippmann seemed to be entirely correct when noting that modern societies had become too complex for the public to understand and be able to make informed decisions. And even thought emerging citizen/participatory journalism ${ }^{36}$ is genuinely beneficial trend, old school journalism is still needed. The later reflects most easily if we compare the news we want to get (by personal choice of platform we use) and the news we need to get (provided by traditional media source). And this is where the substance of journalism needs to settled on.

The news business is in reality one highly dynamic industry that entails equally dynamic schooling. The latter implies the need of journalism schools to invest in human capital, specifically in one trained and skillful enough in new technologies, and in wider university linkage so the schools will include a multi-disciplinary appro- ach of educational process, investment in adequate hardware and software to utilize the performance requirements of the classes and last but not least - broader curricu- lum review undertaken in the light of enormous changes and challenges imposed by digital technology development in communications of every kind.

Let us assume that although political, social, economic and media system vary and differ somewhat widely from country to country just as the levels of development and journalism cultures do, the changes and challenges facing journalism and journalism education around the world are largely similar and exist universally ${ }^{37}$. The evidence of the latter is best demonstrated in part I of this article where the

\footnotetext{
${ }^{34}$ Hemida contributes to the discussion concerning the Lippmann-Dewey debate / philosophical discussion on democracy and the media in his paper Participatory Journalism in Online Newspapers: Guarding the Internet's Open Gates, Jane B. Singer, Alfred Hermida, David Domingo, Ari Heinonen, Steve Paulussen, Thorsten Quandt, Zvi Reich and Marina Vujnovic, Wiley-Blackwell, April 2011. p. 3.

${ }^{35}$ Ibid., p. 3.

${ }^{36}$ Professional news outlets are providing numerous opportunities for the public to contribute. The study done by Alfred Hemida draws on the perspectives of Walter Lippmann and John Dewey to examine how journalists view participatory journalism. Based on interviews with journalists from two dozen newspaper websites, as well as a consideration of those sites, we suggest that news professionals view the user as an active recipient of the news. As active recipients, users are framed as idea generators and observers of newsworthy events at the start of the journalistic process, and then in an interpretive role as commentators who reflect upon professionally produced material. Further reading Participatory Journalism in Online Newspapers: Guarding the Internet's Open Gates, Jane B. Singer, Alfred Hermida, David Domingo, Ari Heinonen, Steve Paulussen, Thorsten Quandt, Zvi Reich and Marina Vujnovic, Wiley-Blackwell, April 2011

${ }^{37}$ Global Journalism education: A conceptual approach, Mark Deuze, Routledge, Journalism Studies, Vol. 7, No 1, 2006, introduction
} 
changes and challenges are noted. Hence, the intention was to contribute to the discussion on the future of journalism and journalism education in general and in more or less global manner bearing in mind the conviction that journalism education as socializing agent is prerequisite for the improvement of the society and healthy citizen and that is it immensely important how we educate and how we engage our journalism students and ourselves in a meaningful and preferably non-hierarchical dialogue because this is what can determine how journalism gets done ${ }^{38}$.

\section{REFERENCES}

Article in Guardian, http://www.guardian.co.uk/media/ 2011/jun/26/ digital-firstwhat-means-journalism

Article in Guardian, http://www.guardian.co.uk/media/ 2011/sep/04/andy-carvintweets-revolutions

Bardoel, J., Deuze, M. (2001), „Network Journalism: Converging Competences of Media Professionals and Professionalism“, Australian Journalism Review, Vol. 23, No. 2, pp. 91-103.

Deuze, M. (2006), „Global Journalism education: A conceptual approach“, Journalism Studies, Vol. 7, No 1, pp. 19-34.

Dealing with User-Generated Content: is it Worth it? (2009), by Paul Hamleton, from The Future of Journalism Papers from a conference organized by the BBC College of Journalism, edited by Charles Miller, CoJo Publications: 1, BBC College of Journalism, Digital First, CEO John Paton's Dialogue with Digital First Media employees and the Public On How A Newspaper Company becomes A Digital First Company, http://jxpaton.wordpress.com/

Ecole Supierieure de Journalisme (Paris, France), http://www.esj-paris.com

From Introducing Multimedia to the Newsroom (2009), Zoe Smith, from The Future of Journalism Papers from a conference organized by the BBC College of Journalism, edited by Charles Miller, CoJo Publications: 1, BBC College of Journalism

\footnotetext{
${ }^{38}$ Regarding the feasibility of a global approach to conceptualizing journalism education we need to under-line Mark Deuze writing and his notes on specific examples of international cooperation projects in assessing the needs of a changing journalism training and education environment. Namely, he call the attention to the following initiatives: 1) In Europe: the various publications and programs on journalism training of the European Journalism Centre in Maastricht, The Netherlands, coupled with emerging undergraduate and graduate international collaborative programs in "Eurojournalism" by schools and universities in Wales, Denmark, Germany and the Netherlands. 2) In Africa: audits, reports and programs by the Southern Africa Media Training Trust and the Media Institute of Southern Africa, as well as overviews offered by media professionals in the field. 3) In the Asia-Pacific region: various collaborations of schools, media institutions and universities in the region including partners in Europe and the United States. 4) In South America: research and training programs for the entire region initiated by the Ciespal Institute in Quito, Ecuador. 5) Worldwide: the UNESCO initiative Journet, a self-proclaimed global network for professional education in journalism and the media. Ibidem., p. 20 and p. 31
} 
Gillmor, D. (2008), „Principles for new media literacy, Media Republic“, Papers Berkman Center for Internet and Society at Harvard University, http://cyber. law.harvard.edu/sites/cyber.law.harvard.edu/ files/Principles\%20for\%20a\%20New\%20Media\%20Literacy_MR.pdf

Guardian: Article on data journalism, http://www.guardian. co.uk/news/datablog /2011/sep/26/data-journalism-guardian

Singer, J.B. et al. (2011), Zvi Reich and Marina Vujnovic Participatory Journalism in Online Newspapers: Guarding the Internet's Open Gates, Wiley-Blackwell, April.

Informing communities: Sustaining Democracy in the Digital Age, Posted by Knight Comm on Apr 07, 2010 in Civic Engagement, Digital Literacy, Local Journalism, Open Government, Public Service Media, Universal Broadband. http:// www. knightcomm.org/read-the-report-and-comment/

The Information needs of communities (2011), Steven Waldman and the Working Group on Information Needs of Communities, Federal Communications Commission, http://www.fcc.gov/infoneed-sreport

University Journalism Education: A Global Challenge, A Report to the Center for International Media Assistance (2007), August 1, http://www.ned.org/cima/ CIMA-University_Journalism_Education-Report.pdf

Model Curricula on Journalism education, UNESCO series on journalism education, UNESCO 2007 Journalism education's four transformational trends, Eric Newton, http://www.knightfoundation.org/blogs/knightblog/2010/ 8/4/aejmc/

Missouri School of Journalism (University of Missouri, USA) http://journalism. missouri.edu/about/history.html

CNN IReport, http://ireport.cnn.com/

Reinvigorating Journalism Education, A Review of News 21, 2005-2011, June 1, 2011, JM Advisory group The Commission on Freedom of the Press, A Free and Responsible Press - A General Report on Mass Communication: Newspapers, Radio, Motion Pictures, Magazines and Books, 20 (1947) 